\title{
DEKONSTRUKSI AKAR KORUPSI DARI POLA KEMITRAAN ANTARA JAKSA DENGAN PIMPINAN DAERAH
}

\author{
Siti Marwiyah \\ Fakultas Hukum Universitas Dr. Soetomo \\ Jl. Semolowaru No.84, Menur Pumpungan, Sukolilo, Kota Surabaya, Jawa Timur 60118 \\ Email: marwiyahsh.mh_siti@yahoo.co.id
}

\begin{abstract}
Syndicated of corruption is not easily exposed, especially involving the law enforcement with local leader (Mayor/Regent) who has problem with the management of state money. The root of corruption problem is not only related to the person, but also the law enforcement who both slip into a safety or protector againts the corruptors. These officers provide themselves as service providers for those who intend to collaborate in corrupt.
\end{abstract}

Keywords: Corruption, Prosecutor, Partnership, Mayor, Regent

\begin{abstract}
ABSTRAK
Sindikasi korupsi tidak mudah dibongkar, terutama yang melibatkan aparat penegak hukum dengan pimpinan daerah (walikota/bupati) yang bermasalah dengan pengelolaan uang Negara. Problem akar korupsinya tidak sebatas berhubungan dengan ulah para oknum, tetapi juga aparat penegak hukum yang sama-sama tergelincir menjadi pengaman atau pelindung terhadap sepak terjang koruptor. Para aparat ini menyediakan dirinya sebagai pemberi jasa atas siapa yang bermaksud mengajaknya berkolaborasi untuk melakukan korupsi.
\end{abstract}

Kata kunci: Korupsi, Jaksa, Kemitraan, Walikota, Bupati

\section{PENDAHULUAN}

Kongres Perserikatan Bangsa Bangsa ke 8/1990 di Havana dalam laporannya sudah menyatakan hakikat bahaya atau dampak serius korupsi, yaitu dapat menghancurkan efektivitas potensial semua program pemerintah, dapat mengganggu atau menghambat pembangunan dan menimbulkan korban individual dan kelompok. Sementara dalam Kongres Perserikatan Bangsa Bangsa ke-9/1995 di Kairo juga sudah disebutkan bahwa korupsi dapat membahayakan stabilitas dan keamanan masyarakat, merusak nilai-nilai demokrasi dan moralitas, dan membahayakan pembangunan sosial, ekonomi dan politik. ${ }^{1}$ Dari sejumkah pertemuan nasional maupun internasional, sudah banyak disebutkan mengenai bahaya korupsi. Sayangnya para pejabat di sejumlah Negara, baik dari pusat maupun daerah, masih suka memilih melakukan korupsi.

Selain itu, hasil dari UN Convention Against Corruption 2003 diantaranya menyatakan bahwa korupsi adalah ancaman

1 Haryadi, Dwi. Bahaya Korupsi dan Integritas Penegak Hukum. Diakses pada Juni 11, 2017. Dari UBB: http://www.ubb.ac.id/menulengkap.php?judul=BAHAYA\%20KORUPSI\%20DAN\%20INTEGRITAS\%20PE NEGAK\%20HUKUM\&\&nomorurut_artikel=398. 
bagi keamanan dan kestabilan masyarakat, merusak nilai-nilai dan lembaga-lembaga demokrasi, merusak nilai-nilai moral dan keadilan, membahayakan "pembangunan yang berkelanjutan" dan "rule of law" dan mengancam stabilitas politik. ${ }^{2}$

Bukan hanya itu saja, tidak jauh berbeda dengan hasil konvensi tersebut, Kongres Perserikatan Bangsa Bangsa XI tahun 2005 juga menyatakan tentang hakikat bahaya atau ancaman serius korupsi, yaitu merintangi kemajuan atau progresifitas sosial, ekonomi dan politik, sumber daya masyarakat dialokasikan tidak efisien, meningkatnya ketidakpercayaan terhadap lembaga-lembaga politik, produktivitas menurun, efisiensi administratif berkurang, merusak atau mengurangi dan bahkan mendestruksi legitimasi tatanan politik dan mengganggu pembangunan ekonomi yang berakibat pada ketidakstabilan politik, lemahnya infrastruktur, sistem pendidikan dan kesehatan dan pelayanan sosial lainnya. ${ }^{3}$

Pemerintahan Daerah yang baik (good local governance) merupakan isu yang paling mengemuka dalam pengelolaan administrasi publik dewasa ini di tengah maraknya kasus korupsi. Tuntutan gagasan yang dilakukan masyarakat kepada pemerintah untuk pelaksanaan penyelenggaraan pemerintahan daerah yang baik adalah sejalan dengan meningkatnya pengetahuan masyarakat di samping adanya globalisasi pergeseran paradigma pemerintahan dari "rulling government" yang terus bergerak menuju "good governance" dipahami sebagai suatu fenomena berdemokrasi secara adil dan berkeadaban. Untuk itu perlu memperkuat peran dan fungsi Dewan Perkawilan Daerah (untuk selanjutnya disebut dengan DPRD) agar eksekutif dapat menjalankan tugasnya dengan baik. $^{4}$ Sayangnya, mengharapkan sangat besar pada peran DPRD sekarang ini juga perlu dipertanyakan, karena tidak sedikit elemen DPRD yang tersangkut perkara korupsi

DPRD yang seharusnya mengontrol jalannya pemerintahan agar selalu sesuai dengan aspirasi masyarakat, bukan sebaliknya merusak dan mengkondisikan Eksekutif untuk melakukan penyimpangan-penyimpangan terhadap aturan-aturan yang berlaku, melakukan kolusi dalam pembuatan anggaran agar menguntungkan dirinya, serta setiap kegiatan yang seharusnya digunakan untuk mengontrol eksekutif, justru sebaliknya digunakan sebagai kesempatan untuk "memeras" eksekutif sehingga eksekutif

2 Mulyono, Sidik. (2015), Dibutuhkan Jurus Istmewa Mengalahkan Kejahatan Istimwa, Jakarta: Intan Media, HIm. 34.

3 Ibid. Hlm. 35.

4 Kartiwa, A. Implementasi Peran dan Fungsi Dewan Perwakilan Rakyat Daerah dalam Rangka Mewujudkan "good governance". Diakses Juni 10, 2016. Dari Pustaka: http://pustaka.unpad.ac.id/wpontent/uploads/2009/05/implementasi_peranfungsi_dprd.pdf. 
perhatiannya menjadi lebih terfokus untuk memanjakan anggota DPRD dibandingkan dengan masyarakat keseluruhan. Dengan demikian tidak aneh, apabila dalam beberapa waktu yang lalu beberapa anggota DPRD dari berbagai Kota/Kabupaten ataupun provinsi banyak yang menjadi tersangka atau terdakwa dalam berbagai kasus yang diindikasikan korupsi. Hal ini yang sangat disesalkan oleh semua pihak, perilaku kolektif anggota dewan yang menyimpang dan cenderung melanggar aturan-aturan hukum yang berlaku. ${ }^{5}$

Meskipun maraknya korupsi di DPRD itu secara kasat mata banyak diketahui masyarakat namun yang diadili dan ditindak lanjuti oleh aparat penegak hukum, sangatlah sedikit atau belum diberlakukan supremasi berdasar keadilan untuk semua (justice for $a l l)$. Faktor ini dapat memicu ketidakpuasan atau "perlawanan" masyarakat terhadap supremasi hukum di negara kita. Norma yuridis yang diproduk legislatif dianggap sebagai produk kesepakatan atau kompromikompromi yang berujung bargaining. Elit politik yang seharusnya memberikan contoh dan teladan yang baik kepada masyarakat justru melakukan tindakan-tindakan atau perbuatan-perbuaan yang tidak terpuji, memperkaya diri sendiri, dan bahkan melakukan pelanggaran hukum secara kolektif atau berjamaah. ${ }^{6}$

Selain itu, lemahnya penegakan hukum (law enforcement) ini dapat memicu dan memperluas terjadinya korupsi secara kolektif oleh elit politik terutama di kalangan anggota DPRD. ${ }^{7}$ Kelemahan inilah yang membuat kepercayaan masyarakat terhadap peranperan yang dilakukan DPRD berkurang. Masyarakat menilai, bahwa peran yang dilakukan oleh DPRD sekedar mencari keuntungan di balik peran atau fungsi yang dijalankan.

\section{PEMBAHASAN}

\section{Penanggulangan Korupsi}

Dimensi negatif yang menjadi dampaknya perilaku politisi itu kemudian tercatat, misalnya adanya julukan publik kalau komunitas elit politik Indonesia belum berhasil menunjukkan keteladanan sebagai manusia-manusia utama dalam kinerja yang berbasis moralitas dan norma-norma lain yang dibenarkan, sebaliknya mereka telah terjerumus dalam perilaku-perilaku yang menyimpang dari panduan perilaku (code of conduct) yang sudah dibuatnya sendiri. Panduan berperilaku yang dibuatnya ini adalah kode etik DPRD. Kode etik berperilaku ini merupakan kumpulan norma yang digunakan oleh organisasi dan

\footnotetext{
5 Ibid.

6 Atmojo, Sumarno. (2016), Membedah Akar Korupsi di DPRD, Makalah, Surabaya, Sekteratiat Pusat Studi Pemberantasan Korupsi, Hlm. 2.

7 Ibid.
} 
masyarakat untuk menilai sikap dan perilaku DPRD. Peran kode etik ini juga ikut menentukan potret negara hukum, karena dalam kode etik ini terurmus norma yang mengatur perilaku DPRD. ${ }^{8}$ Kode etik yang semestinya menjadi referensi atau panduan berpersikap dan berperilaku diabaikannya, mereka tidak takut dengan sanksi moral dan organisasi.

Pergeseran itu juga mengakibatkan terjadinya perubahan dalam pola berperilaku secara individual maupun kolektif (kelompok). Sayangnya perubahan ini bukannya memberikan kontribusi positif bagi kehidupan masyarakat dan negara, melainkan justru mengakibatkan banyaknya muncul problem baru, yang polanya lebih buruk dibandingkan sebelum terjadinya pergeseran kekuasaan itu. Pola berelasi politik yang membawa perubahan atau reformasi bermakna (bermanfaat) bagi kehidupan masyarakat tidak dimasukkan sebagai substansinya. Sikap-sikap yang ditunjukkan dan pola perilaku yang dibangun oleh unsur rezim baru tidak lebih cacat moral dibandingkan sebelumnya. Rasa optimisme terhadap terjadinya pembaharuan di tengah masyarakat semakin jauh dari harapan akibat perilaku unsur elit yang bertolak belakang dengan aspirasi masyarakat.
Dimensi negatif yang menjadi dampaknya perilaku politisi itu kemudian tercatat, misalnya adanya julukan publik kalau komunitas elit politik Indonesia belum berhasil menunjukkan keteladanan sebagai manusia-manusia utama dalam kinerja yang berbasis moralitas dan norma-norma lain yang dibenarkan, sebaliknya mereka telah terjerumus dalam perilaku-perilaku yang menyimpang dari panduan perilaku (code of conduct) yang sudah dibuatnya sendiri. Panduan berperilelaku yang dibuatnya ini adalah kode etik DPRD. Kode etik berperilaku ini merupakan kumpulan norma yang digunakan oleh organisasi dan masyarakat untuk menilai sikap dan perilaku DPRD. Peran kode etik ini juga ikut menentukan potret negara hukum, karena dalam kode etik ini terurmus norma yang mengatur perilaku DPRD. ${ }^{9}$

Masyarakat sekarang tergolong masyarakat kritis terhadap perkembangan yang terjadi di sekitarnya, terutma di dunia politik. Perilaku elit politik dijadikan sebagai obyek penilaian. Perilaku DPRD misalnya termasuk yang tidak lepas dari opini publik, karena mereka selain menjadi representasi suara rakyat atau perwujudan kekuatan rakyat melalui produk pesta demokrasi (Pemilu), mereka juga tergolong komunitas elit yang peran-perannya telah atau sedang menjadi

\footnotetext{
8 Suseno, Franz Magnis. (1994), Etika Politik; Prinsip-prinsip Moral Dasar Kenegaraan Modern, Jakarta: Gramedia Pustaka Utama, Hlm. 295.

$9 \quad$ Ibid. Hlm. 295.
} 
obyek penilaian dan gugatan, diantaranya menyangkut pola kerjanya yang bermisikan memperjuangkan aspirasi rakyat, produktifitasnya di bidang pembaharuan hukum nasional, serta pola kemitraan yang dibangunnya dengan eksekutif dalam menjalankan roda pemerintahan baik di tingkat pusat maupun daerah. Pola kemitraan yang dibangun antara legislatif (DPRD) dengan eksekutif diposisikan sebagai sumber problem sosial-politik yang selama ini terjadi.

Dalam hubungannya dengan eksekutif itulah yang kemudian menempatkan DPRD mendapatkan banyak stigma buruk sebagai komunitas elite strategis yang berada di lingkaran penyelenggaraan manajemen pemerintahan yang tidak mewakili rakyat, tetapi mewakili kepentingan dan obsesi dirinya sendiri, golongan, keluarga, dan partai politiknya, dan bahkan tidak sedikit diantaranya yang jadi tersangka kasus-kasus bertemakan KKN (Korupsi, Kolusi, dan Nepotisme). Bangunan pemerintahan tidak lagi menjadi potret pemerintahan yang bersih (clean government) akibat perilaku kemitraan yang disalahgunakan atau disalahfungsikan dalam implementasinya atau pelaksanaannya. Pemerintahan di daerah pun seringkali terkena masalah hukum akibat pola kemitraan yang salah dalam penerapannya.

Problem besar dalam kehidupan kenegaraan dapat terjadi akibat maraknya kasus penyalahgunaan kekuasaan, gagalnya memberdayakan demokrasi, gagalnya menjaga tegaknya hak-hak asasi manusia, meminggirkan atau menodai citra diri negara sebagai negara hukum, dan membuka ruang gelap tampilnya kekuatan politik dalam mendahulukan absolutisme, totalitarianisme, diktatorianisme,dan anarkisme, serta kultur korupsi dimana-mana. ${ }^{10}$

Korupsi sangat berbahaya bagi sosial ekonomi masyarakat. Korupsi di bidang pendidikan misalnya, akan menghambat siswa belajar karena keterbatasan sarana dan prasarana. Uang 6,7 trilyun dalam kasus Centurygate setidaknya dapat diberikan sebagai beasiswa sebanyak 1 juta rupiah kepada 6.700.000 siswa. Dengan melihat multi effect dari korupsi di atas, sangatlah wajar jika korupsi dikategorikan sebagai extra ordinary crime dengan berbagai dimensinya, seperti economic crime, organized crime, white collar crime dan political crime. Dengan bentuknya yang extra ordinary crime, maka upaya pencegahan dan pemberantasan korupsi harus ditempuh dengan cara-cara yang luar biasa pula. ${ }^{11}$

Tentu saja penaggulangan korupsi itu bukan hanya dipundak lembaga penegak hukum yang dibentuk secara khusus oleh negara seperti Komisi Pemberantasan Korupsi (KPK), tetapi juga oleh lembaga-lembaga lain seperti Kejaksaan.

\footnotetext{
${ }^{10}$ Munir, Misbahul. (2004), Pemilu, Demokrasi, dan Ijtihad Politik Perempuan, Surabaya: Visipres. Hlm. 82-83.
}

11 A. Kartiwa, Loc. Cit. 


\section{Peran Strategis Jaksa}

Jaksa Penuntut Umum (JPU) adalah seseorang yang diberi wewenang oleh undang-undang untuk melakukan penuntutan dan pelaksanaan Penetapan Hakim. Berdasarkan Pasal 33 Undang-undang No. 16 Tahun 2004 tentang Kejaksaan (untuk selanjutnya disebut dengan UU Kejaksaan), dalam melaksanakan tugas dan wewenangnya, Jaksa membina hubungan kemitraan dengan badan penegak hukum dan keadilan serta badan negara atau instansi lainnya.

Meskipun JPU diberi peran secara yuridis untuk berelasi dengan badan negara atau institusi peradilan lainnya, namun kemitraan yang dibangunnya ini atas dasar kepentingan penegakan hukum, dan bukan sebaliknya menjadi penghambatnya.

JPU dalam ranah itu mempunyai peran bukan hanya mencegah dunia peradilan bersih dari praktik kotor, namun juga membersihkan kotoran yang bersarang di tubuhnya sendiri atau pihak-pihak lainnya. Untuk tugas bersihbersih ini, jaksa wajib membentuk integritas dirinya. Bagaimana mungkin jaksa kapabel dalam membersihkan kotoran misalnya, kalau dalam dirinya terjangkit beragam kotoran? atau bagaimana mungkin dunia peradilan bisa dibersihkan, kalau dirinya merupakan bagian dari kotoran? atau bagaimana bagaimana jaksa mampu menghabisi kalau mental korup kesulitan dibersihkan di lingkungan korp kejaksaan?

Kita tahu korupsi itu penyakit yang mengerikan. Secara umum korupsi dari sudut pandang hukum adalah tindak pidana yang secara garis besar mencakup unsur-unsur sebagai berikut: pertama, perbuatan melawan hukum, kedua, penyalahgunaan kewenangan, kesempatan, atau sarana, ketiga, memperkaya diri sendiri, orang lain, atau korporasi, keempat, merugikan keuangan negara atau perekonomian negara. ${ }^{12}$

Korupsi berawal dari bahasa latin "corruption" atau "corruptus". Corruptio berasal dari kata corrumpere, suatu kata latin yang lebih tua. Dari bahasa latin itulah turun ke banyak bahasa Eropa seperti Inggris yaitu corruption, corrupt; Prancis yaitu corruption; dan Belanda yaitu corruptie, korruptie. Dari Bahasa Belanda inilah kata itu turun ke Bahasa Indonesia yaitu korupsi, yang kemudian menjadi demikian akrab sebagai penyakit serius yang sebagian orang membenci dan memusuhinya, tapi sebagian lainnya sangat menyukainya, ${ }^{13}$ atau sebaian orang Indonesia tidak mau kalau tidak ikut menjadi bagian dari penyakit bangsa.

$12 \ldots$ __ Pengertian Korupsi dan Dampak Negatif. Diakses Juni 5, 2016. Dari Pakar Bisnis: http://pakarbisnisonline.blogspot.com/2009/12/pengertian-korupsi-dan-dampak-negatif.html,

13 Hermawan, (2010) Korupsi Tanpa Tanding, Episode Keberlanjutan Keterpurukan Indonesia, Jakarta: LPKIPembebasan Indonesia. Hlm. 12. 
Logis jika dengan tugas mulia itu, jaksa diberi rambu-rambu secara yuridis untuk menjadi aparat penegak hukum yang berintegritas. Berdasarkan Pasal 8 UU Kejaksaan, seorang jaksa penuntut umum dalam pelaksanaan tugas dan wewenang senantiasa bertindak berdasar hukum, mengindahkan norma-norma keagamaan, kesopanan, dan kesusilaan, serta wajib menggali dan menjunjung tinggi nilai-nilai kemanusiaan yang hidup dalam masyarakat, serta senantiasa menjaga kehormatan dan martabat profesinya.

Norma itu jelas menunjukan, bahwa jaksa tu dituntut harus menjaga kehormatan profesinya. Terhadap setiap peran yang dilakukan dalam penegakan bangunan sistem peradilan pidana (criminal justice system), jaksa wajib membentuk dirinya sebagai aparat yang taat dalam beragama dan berperilaku sesuai dengan hukum, dan bukan menjadi menjadi pembangkangnya.

Selain tuntutan berintegritas itu, jaksa dalam melaksanakan bidang penuntutan, harulah dilaksanakan secara merdeka atau terlepas dari pengaruh kekuasaan pemerintah dan kekuasaan lainnya. Hal ini didasarkan Pasal 2 UU Kejaksaan. Sedangkan secara khusus pada Jaksa Agung diatur dalam pasal 37 ayat (1) ditegaskan, Jaksa Agung bertanggungjawab atas penuntutan yang dilaksanakan secara independen demi keadilan berdasarkan hukum dan hati nurani.
Landasan yuridis itu sudah menentukan, bahwa keberadaan jaksa itu sebagai penanggungjawab fundamental di ranah penuntutan. Model penuntutan yang dituntut oleh UU Kejaksaan, adalah model penuntutan yang dilaksanakan jaksa tanpa campur tangan pihak manapun.

Setiap penuntutan yang dikonstruksi, wajiblah berlandaskan pasal-pasal yang sudah menggariskannya, dan bukan karena adanya pesanan atau desakan atau relasi kemitraan dengan pihak eksekutif, seseorang atau sekelompok orang yang berperkara, maupun kekuatan politik tertentu.

Karena posisinya sebagai penanggungjawab utama di ranah itu, maka idealnya Jaksa mampu mengonstruksi pola kemitraan yang didasarkan kepentingan hukum. Hubungan yang dibangun dengan badan-badan negara, yang diperbolehkan berdasarkan Pasal 33 UU Kejaksaan, haruslah menjadi hubungan hukum, bukan hubungan atas dasar kepentingan lainnya.

Hubungan hukum itu, salah satunya dapat dideskripsikan seperti berikut ini, bahwa sebagai penyidik dalam tindak pidana atau kejahatan korupsi maka kejaksaan berwenang untuk mengadakan penyelidikan dan penyidikan. Setelah penyidikan dirasa oleh penyidik sudah selesai maka berkas perkaranya diserahkan kepada kejaksaan selaku penuntut umum. Jaksa yang ditunjuk sebagai penuntut umum (JPU) setelah menerima berkas perkara segera memeriksa, 
apabila berkas oleh penuntut umum dianggap kurang lengkap maka dalam waktu tujuh hari atau sebelumnya, penuntut umum harus sudah mengembalikan berkas pada penyidik disertai dengan petunjuk untuk kelengkapan berkas tersebut. Apabila dalam waktu tujuh hari setelah menerima berkas perkara dari penyidik penuntut umum tidak mengembalikan berkas perkara (BAP), maka berkas tersebut sudah lengkap. Dengan dikembalikannya berkas perkara oleh penuntut umum pada penyidik disertai dengan petunjuk untuk kelengkapan berkas maka penyidik harus mengadakan penyidikan lanjutan guna melengkapi berkas selambatlambatnya dalam waktu empat belas hari selesai dan dikirim lagi pada penuntut umum. ${ }^{14}$

Seharusnya hubungan hukum kepada siapapun, termasuk badan-badan Negara, diimplementasikan oleh jaksa. Sayangnya, tidak sedikit jaksa yang memerankan dirinya sebagai "penjahat" profesi. Mereka tidak menjadi sosok yang mencerminkan aparat penegak hukum yang suka bekerja keras dan tidak gentar menghadapi siapapun yang bermaksud mempengaruhi dan melumpuhkan peran penegakan hukumnya, tetapi terseret menjadi aparat yang menguntungkan tersangka/terdakwa, khususnya ketika yang menjadi tersangka/terdakwa ini dari pucuk pimpinan daerah (Bupati/Walikota).
Penulis dan kawan-kawan yang melakukan riset mengenai transparansi pemeriksaan yang dilakukan oleh jaksa terhadap Bupati/Walikota yang diduga melakukan penyalahgunaan uang negara, menunjukkan, bahwa pelaksaanan pemeriksaannya tidak bisa dikatakan transparan, karena selain publik tidak diberikan informasi mengenai perkembangan kasus yang ditanganinya, juga antara Jaksa sebagai pemeriksa dengan yang diperiksa (Bupati/Walikota) dijumpai sering melakukan pertemuan-pertemuan.

Diingatkan, bahwa dalam penuntutan dilaksanakan secara merdeka terlepas dari pengaruh kekuasaan pemerintah dan pengaruh kekuasaan lainnya. Kejaksaan sebagai salah satu lembaga penegak hukum dituntut lebih berperan dalam menegakkan supremasi hukum, perlindungan kepentingan umum, penegakan hak asasi manusia, serta pemberantasan korupsi. ${ }^{15}$

Jaksa yang berintegritas dan independen sebenarnya dapat memberikan solusi terhadap penanganan kasus-kasus secara obyektif, jujur dan benar. Sayangnya, tidak sedikit jaksa yang terlibat problem malapraktik profesi. Dari malapraktik profesi inilah, selain korp kejaksaan bercitra buruk, juga ditempatkan sebagai salah satu akar masalah serius yang menyebabkan pimpinan daerah melakukan penyalahunaan jabatannya.

\footnotetext{
${ }^{14}$ Sutarto, Suryono . (2004), Hukum Acara Pidana Jilid I. Semarang: Universitas Diponegoro. Hlm. 76.

${ }^{15}$ Hartanti, Evi. (2005), Tindak Pidana Korupsi, Jakarta: Sinar Grafika. Hlm. 23.
} 
Jaksa itu mengadakan hubungan dengan eksekutif seperti Bupati/Walikota atau pimpinan-pimpinan SKPD, yang terlibat perkara penyalahgunaan kekuasan seperti melakukan penyalahgunaan uang negara (APBN dan APBD), yang karena hubungan baiknya, jaksa tidak berani transparan dalam menangani kasusnya.

Ketidakseriusan jaksa menangani kasuskasus di lingkungan pemerintahan daerah dapat terbaca lewat seringnya forum-forum pertemuan Muspida atau lainnya, yang diantaranya melibatkan pimpinan KEJARI dengan Bupati/Walikota, yang kondisi pemerintahan daerah dimana jaksa ini bertugas, diindikasikan Bupati/Walikota terlibat penyalahgunaan kekuasaan, padahal idealitasnya Jaksa menurut kode etik profesinya, sebagaimana hakim, dilarang bertemu dalam jamuan makan atau pertemuan yang bukan untuk kepentingan penegakan hukum.

Dalam ranah itu, Jaksa terperangkap dalam kultur yang mengeliminasi cita-cita penegakan hukum. Kegagalan institusi kejaksaan secara umum dalam penanganan kasus korupsi diindikasikan berelasi dengan tidak militannya jaksa saat menghadapi oknum aparat pemerintah daerah yang terlibat korupsi.

Ketidakmilitansian jaksa itu menempatkannya sebagai segmentasi dari pilar yudisial yang menyerah di tangan koruptor. Mereka bukan hanya gagal memerangi koruptor, tetapi juga menjadi bagian dari lingkaran setan korupsi.

Jaksa seperti itu sejatinya sebagai penyelingkuh hukum yang "diberi” ruang anomali oleh korp-nya, sehingga membuatnya ikut memainkan hukum seperti yang diskenario para koruptor. Norma yuridis dikondisikan sebagai instrumen yang terkooptasi dan tereduksi oleh keserakahannya mengumpulkan kekayaan sebanyak-banyaknya.

\section{PENUTUP}

Rezim Jokowi yang menginginkan terwujudnya pemerintahan yang bersih dan berwibawa ini, wajib ditopang oleh jaksa yang selain berintegritas moral tinggi, juga kapabel dalam menunjukkan independensinya. Hal inilah yang membutuhkan pengaturan baru, bukan hanya kode etik, yang mengatur pola hubungan kemitraan antara jaksa dengan Bupati/Walikota yang terlibat masalah korupsi. Pengadaan regulasi atau pembaruan hukum dibutuhkan agar selain jaksa dan Bupati/Walikota mempunyai kepastian hukum dalam membangun kemitraannya, juga untuk mencegah kecenderungan pembenaran sikap dan meluasnya perilaku Bupati/Walikota akibat menempatkan dirinya lebih tinggi dan superior dibandingkan dengan jaksa. Kalau sejak dini, sikap dan perilaku Bupati/Walikota mampu dikendalikan, maka atmosfir korupsi profesi 
diantara pola kemitraan antara jaksa dengan

Bupati/Walikota bisa dicegah.

\section{DAFTAR PUSTAKA}

\section{Buku}

Atmojo, Sumarno. (2016), Membedah Akar Korupsi di DPRD, Makalah, Surabaya: Sekteratiat Pusat Studi Pemberantasan Korupsi.

Hartanti, Evi. (2005), Tindak Pidana Korupsi, Jakarta: Sinar Grafika.

Hermawan, (2010) Korupsi Tanpa Tanding, Episode Keberlanjutan Keterpurukan Indonesia, Jakarta: LPKI-Pembebasan Indonesia.

Mulyono, Sidik. (2015), Dibutuhkan Jurus Istmewa Mengalahkan Kejahatan Istimwa, Jakarta: Intan Media.

Munir, Misbahul. (2004), Pemilu, Demokrasi, dan Ijtihad Politik Perempuan, Surabaya: Visipres. Hlm. 82-83.
Suseno, Franz Magnis. (1994), Etika Politik; Prinsip-prinsip Moral Dasar Kenegaraan Modern, Jakarta: Gramedia Pustaka Utama.

Sutarto, Suryono . (2004), Hukum Acara Pidana Jilid I. Semarang: Universitas Diponegoro.

\section{Internet}

Pengertian Korupsi dan Dampak Negatif. Diakses Juni 5, 2016. Dari Pakar Bisnis: http://pakarbisnisonline.blogspot.com/2009/ 12/pengertian-korupsi-dan-dampaknegatif.html,

Haryadi, Dwi. Bahaya Korupsi dan Integritas Penegak Hukum. Diakses pada Juni 11, 2017. Dari UBB: http://www.ubb.ac.id/menulengkap.php?jud $\mathrm{ul}=\mathrm{B}$ AHAYA $\% 20 \mathrm{KORUPSI} \% 20 \mathrm{DAN} \% 20$ INTEGRITAS\%20PENEGAK\%20HUKU M\&\&nomorurut_artikel=398.

Kartiwa, A. Implementasi Peran dan Fungsi Dewan Perwakilan Rakyat Daerah dalam Rangka Mewujudkan "good governance". Diakses Juni 10, 2016. Dari Pustaka: http://pustaka.unpad.ac.id/wpontent/uploads/2009/05/implementasi_pera nfungsi_dprd.pdf. 